NBER WORKING PAPER SERIES

\title{
READING, WRITING AND RAISINETS: ARE SCHOOL FINANCES CONTRIBUTING TO CHILDREN'S OBESITY?
}

\author{
Patricia M. Anderson \\ Kristin F. Butcher \\ Working Paper 11177 \\ http://www.nber.org/papers/w11177 \\ NATIONAL BUREAU OF ECONOMIC RESEARCH \\ 1050 Massachusetts Avenue \\ Cambridge, MA 02138 \\ March 2005
}

We thank Sara Christopher, Karenne Eng, AJ Felkey, Katharine Anderson, and Fred Yarger for excellent research assistance. Nancy Brener provided advice in using the SHPPS data. We thank Lisa Barrow, David Card, Kevin Hallock, Helen Levy, Thomas Lemieux, Doug Staiger, and participants in UC-Berkeley's labor lunch series, the University of Virginia Bankard Workshop in Public Economics, the 2003 NBER Summer Institute, and the Chicago Fed's brown bag series for helpful discussions. The views expressed here are the authors'and do not necessarily represent those of the Federal Reserve Bank of Chicago or the Federal Reserve System. All errors are our own. This is in no way meant to impugn Raisinets, the Nestle Company or any of its other products. The views expressed herein are those of the author(s) and do not necessarily reflect the views of the National Bureau of Economic Research.

(C) 2005 by Patricia M. Anderson and Kristin F. Butcher. All rights reserved. Short sections of text, not to exceed two paragraphs, may be quoted without explicit permission provided that full credit, including $\odot$ notice, is given to the source. 
Reading, Writing and Raisinets: Are School Finances Contributing to Children's Obesity?

Patricia M. Anderson and Kristin F. Butcher

NBER Working Paper No. 11177

March 2005

JEL No. I1, I2, J1

\begin{abstract}
The proportion of adolescents in the United States who are obese has nearly tripled over the last two decades. At the same time, schools, often citing financial pressures, have given students greater access to "junk" foods, using proceeds from the sales to fund school programs. We examine whether schools under financial pressure are more likely to adopt potentially unhealthful food policies. We find that a 10 percentage point increase in the probability of access to junk food leads to about a one percent increase in students' body mass index (BMI). However, this average effect is entirely driven by adolescents who have an overweight parent, for whom the effect of such food policies is much larger (2.2\%). This suggests that those adolescents who have a genetic or family susceptibility to obesity are most affected by the school food environment. A rough calculation suggests that the increase in availability of junk foods in schools can account for about one-fifth of the increase in average BMI among adolescents over the last decade.
\end{abstract}

Patricia M. Anderson

Department of Economics

Dartmouth College

Hanover, NH 03755-3514

and NBER

patty.anderson@dartmouth.edu

Kristin F. Butcher

Federal Reserve Bank of Chicago

Research Department

230 S. LaSalle Street

Chicago, IL 60604

kbutcher@frbchi.org 


\section{Introduction}

Over the past three decades, weight problems among children have grown dramatically. After holding fairly steady at around 5\% during the 1970s, the percent of 12 to 19 year-olds that were obese doubled by the early nineties and exceeded 15 percent by 2000 (Ogden, et al., 2002). ${ }^{2}$ At a basic physiological level, the cause of this increase in overweight status among children is clear: children must be taking in more energy than they expend. What is unclear is what has upset the balance between energy intake and expenditure.

Observers have begun to question the role played by schools, pointing in particular to declines in physical education and increases in the availability of soft drinks and snack foods. New accountability measures, which typically require that students achieve a certain minimum level on standardized tests or the school suffers consequences, may give schools an added incentive to invest resources in core academic curricula and cut back on physical education classes. At the same time, schools may try to raise new money in order to meet the achievement goals while minimizing the need to cut non-core programs. However, the property tax reform movement during the 1970s and 1980s may have limited schools' ability to raise money through traditional means. One way schools can get extra money to maintain optional programs or strengthen core academics is through soft drink and vending contracts, or through other snack food sales. The media is rife with examples of schools cutting deals with soda and snack vending companies in order to increase their discretionary funds. For example, one high school in Beltsville, MD made \$72,438.53 in the 1999-2000 school year through a contract with a soft drink company and another $\$ 26,227.49$ through a contract with a snack vending company. The almost $\$ 100,000$ obtained was used for a variety of activities, including instructional uses such as

\footnotetext{
2 "Obese" here is defined as a BMI above an age-sex specific cutoff defined by the Centers for Disease control. This cutoff corresponds closely to a BMI above the $95^{\text {th }}$ percentile of age-sex specific BMI distributions from the late
} 
purchasing computers, as well as extracurricular uses such as the yearbook, clubs and field trips (Nakamura, 2001). District level contracts can be even more lucrative - one Colorado Springs district, for example, negotiated a 10-year beverage contract for \$11.1 million dollars (DD Marketing, 2003). ${ }^{3}$

The purpose of our study is two-fold. First, we examine whether availability and advertising of snack foods and beverages in schools are related to school financial pressures, as captured by tax and expenditure limits, school accountability measures, state school financing rules, and relative growth in the school aged (local) population. Second, we examine whether availability and advertising of snack foods and beverages in schools can be linked to adolescent obesity. As school districts nationwide debate the benefits and costs of entering into contracts with soda companies or banning the sales or advertising of snacks and sodas on campus it is important to have solid information on which to base these decisions. For example, high-calorie snack foods and beverages may be so ubiquitous that adolescents will consume them whether or not they are available through the school. If that is the case, policy-makers might prefer schools to sell the foods students crave. In that way, at least students are not leaving school to buy snack food (with all the dangers that may entail) and schools can use the extra funds to students' advantage.

The effect of school food policies on children's weight is an important, but difficult to answer, question. Similar to questions about the impact of school quality on children's academic or labor market outcomes, one worries that school characteristics may be correlated with individual or family characteristics in systematic ways. In addition, examining the effect of

1960s and early 1970s, prior to the advent of the current weight problems in children.

${ }^{3}$ While on a per pupil basis these contracts amount to only about 0.5 percent of revenues (authors' calculations based on average revenues in NCES and reports on contracts from DD Marketing), they provide a source of unrestricted funds that may be spent on elective programs. 
school food policies on children's weight problems is difficult because there is no one data set that contains information on children's height and weight, individual and family characteristics that may affect weight problems, and school food policies. We use a two-sample procedure to overcome these difficulties. The two- sample procedure overcomes the data availability challenge because only the information needed to estimate the first stage - in our case these are state and county characteristics -- must be in both samples. As an added benefit, the procedure addresses the problem that school food policies may be endogenously determined. We combine information from the School Health Policies and Programs Study (SHPPS), the National Center for Education Statistics (NCES), the 1990 and 2000 U.S. Censuses, and the National Longitudinal Survey of Youth 1997 (geocode version) to create the two samples that allow us to examine the effect of school food policies on adolescent Body Mass Index (BMI). ${ }^{4}$ We find that there is a positive and often significant effect of predicted availability and advertising of snack foods and beverages on BMI. However, this relationship is driven by those with an overweight parent. We interpret our results to indicate that while for most students, school food policies have no affect on their weight, for those with a family susceptibility for weight gain, these policies that increase access to snack foods and beverages in school may be a contributing factor.

The paper is organized as follows. Section II provides background on the issues of school food policies and obesity in the United States. Section III describes our empirical approach and discusses our main estimates of the relationship between school food policies and finances and of the effect of school food policies on adolescent obesity. Section IV then explores the interaction of school food policy and family susceptibility to weight problems, and Section V concludes.

${ }^{4}$ Body mass index is weight in kilograms divided by height in meters squared. 


\section{Background on School Food Policies and Obesity in the United States}

Public health officials are alarmed at the increase in obesity in the United States. The increase in childhood obesity is particularly worrisome as obesity in childhood has both immediate and long-term health risks, including Type 2 diabetes, hypertension and cardiovascular disease (Ebbeling et. al. 2002), as well as contributing to low quality of life scores (Schwimmer et al. 2003). Using data from the National Health and Nutrition Examination Surveys (NHANES), Anderson, Butcher and Levine (2003a) show that for both children and adults, the BMI distributions for 1971-1974 and 1976-1980 are very similar, particularly in the right tail of the distribution. However, beginning with the 1988-1994 NHANES, this right tail gets thicker. ${ }^{5}$ The obesity "epidemic" does not appear to be a matter of a shift to the right of the entire distribution of BMI. Rather, the distributions suggest that whatever changes have taken place to upset the balance between energy in-take and energy expenditure have not affected everyone in the same way. There appears to be some fraction of the population that is particularly susceptible to obesity, and the conditions have become optimal for their disease to flourish.

It is in this setting that school food policies are currently being hotly debated.

Policymakers are acting on the intuitive notion that having snacks and sodas readily accessible in schools contributes to children's obesity. ${ }^{6}$ Despite movements on the legal and policy fronts, there are very few studies that address whether there is a direct relationship between school food

\footnotetext{
${ }^{5}$ The timing of this change may help focus the investigation of the underlying cause in the increase in childhood obesity. Researchers might fruitfully examine things that changed for children during this period. For example, employment among mothers with young children increased in prevalence and intensity during this period. Anderson, Butcher, and Levine (2003b) examines the role of maternal employment in the probability that a child is obese and finds that increases in mothers' hours of work can potentially explain between 12 to 35 percent of the increase in childhood obesity among the children of highly educated mothers.

${ }^{6}$ For example, New York City public schools recently banned candy, soda and other sugary snacks from school vending machines (Perez-Pena, 2003), similarly the Los Angeles school district has banned the sale of soft drinks during school hours (Fried and Nestle, 2002).
} 
policies and obesity. ${ }^{7}$ What is clear, however, is the pervasiveness of snack foods and beverages in U.S. schools. Data from the School Health Policies and Programs Study (SHPPS) from 1994 and 2000 form a nationally representative sample of schools, and include both public and private schools. As shown in Anderson, Butcher and Levine (2003a), these data reveal two clear patterns. First, availability of junk food increases with grade level. While only 27 percent of elementary schools had vending machines available to students in 2000 , that percentage rises to 67 percent for middle schools and to 96 percent for high schools. Second, in the few questions asked consistently across the two years, availability has increased. For example, while 19 percent of high schools served a brand name fast food in 1994, 26 percent did by 2000 .

Before examining the effect of school food policies on children's weight, we first present measures of BMI and obesity from the NHANES for comparison with the NLSY97 data used in our study. BMI for individuals in the NLSY97 is constructed from self-reported height and weight, while the NHANES includes an examination module where height and weight are measured. In table 1 we report mean, median, and $95^{\text {th }}$ percentile BMI for the NLSY97 analysis sample and for the sub-sample of similarly aged (14 to 20 year old) respondents in the NHANES (1999-2000). Since we control for parental BMI in the analysis below, we also report BMI for parents in the NLSY97 and for similarly aged (32-67 year old) adults in the NHANES.

Columns 1 and 2 in Table 1 show measures of BMI for adolescents. Mean and median BMI are both slightly higher in the NHANES, where height and weight are measured by an examiner, than in the NLSY97, where height and weight are self-reported. However, BMI at the 95th percentile is close to 35 in the NHANES and only 32 in the NLSY97. This translates into

\footnotetext{
${ }^{7}$ Studies on related topics include Ludwig, et al. (2001), Cullen et al. (2000), and Kubik et al. (2003) who examine school food and overall nutrition. Additionally, Pateman, et al. (1995) and Weschler et al. (2001) examine the availability of junk food in schools. Finally, Carter (2002) and Fried and Nestle (2002) speculate about the correlation between school policies and adolescent obesity, but do not formally investigate the relationship.
} 
about 4 percent more adolescents categorized as obese in the NHANES than in the NLSY97 sample. The data for adults shows a similar pattern. Both comparisons suggest that very heavy people are under-reporting their weight in the self-reported data, such that the self-reported data are prone to some measurement error. ${ }^{8}$

\section{Effect of School Food Policies on Adolescent Obesity}

\section{A. Methodology}

Much of our empirical strategy is dictated by the realities of the data at our disposal. In particular, there are no available data sets that include school policies regarding junk food, school financial pressure indicators and individual heights, weights and demographics. Thus, we adopt a two-sample approach (Angrist and Krueger, 1992, 1995). If we had data with all of the elements described above, we could directly investigate the relationship between school policies and student obesity. However, even in this case one would be concerned about bias due to the possible endogeneity of the key food policy variables. Thus, even with access to a richer data set, we would still want to use an instrumental variables approach. While data limitations restrict our ability to estimate the simple OLS relationship between obesity and school food policies in the full sample, our two-sample methodology is essentially an IV estimator and should address the endogeneity issue. ${ }^{9}$

We estimate the first stage using school food policy information from the SHPPS. Specifically, we analyze three policies: junk food availability in schools, whether schools have "pouring rights" contracts, and whether soda and snack food advertisements are allowed at

\footnotetext{
${ }^{8}$ Empirical methods for correcting self-reported height and weight are developed in Cawley (1999), but make no substantive difference in this analysis.

${ }^{9}$ For a sub-sample of the data, we can directly match the county-level policy data with the individual data. In this case, the true IV point-estimates are very close to those obtained using the two sample method with these data.
} 
schools or school events. ${ }^{10}$ We aggregate these to the county level using the SHPPS school weights. Our first stage, then, estimates the fraction of schools in a county with these policies as a function of county, state, and regional characteristics. County characteristics include the growth rate of the school age population relative to total population in the county, calculated from the 1990 and 2000 U.S. Censuses. ${ }^{11}$ Next, we control for the fraction of school finances that come from the state, calculated from the NCES data. The NCES provides this information at the district level and we use district enrollments to aggregate to the county level. The state characteristics include an indicator variable for whether the state has a tax or expenditure limitation and an indicator for whether the state has passed a school accountability measure. ${ }^{12}$ We also include a vector of three region dummies, $\boldsymbol{R}$ (the excluded category is the West). Specifically, we estimate the following:

$$
\begin{aligned}
& \text { policy }_{c}=\gamma_{0}+\gamma_{1} \text { relative school-age population growth rate } \\
& \\
& \text { state }_{c}+\gamma_{3} \text { tax }_{\text {fimitation }}+\gamma_{4} \text { accountability }_{s}+\gamma_{5} \boldsymbol{R}_{s}+\omega_{c}
\end{aligned}
$$

where the c subscript represents county and the s subscript represents state.

The relative growth in the school-age population is meant to capture budgetary pressure on the school system, thus we expect $\gamma_{1}$ to be positive. If the share of children has grown relative to the share of adults, then there may be more financial pressure on schools, and they may be

\footnotetext{
However, the two-sample method sacrifices efficiency, resulting in larger standard errors. See appendix table 2.

${ }^{10}$ See data appendix for more details. "Junk Food Available" means that students can buy chocolate, candy, cakes, ice cream, or salty snacks (that are not fat free) from a machine or school store. "Pouring Rights" contract means the school has agreed to sell one brand of soft drinks, often in exchange for a percentage of sales or other incentive packages. "Soda or Snack Food Advertisements" means that advertisements are allowed at least at one type of school related activity or in one or more places at the school - for example, on a school bus, at a school sporting event, on school grounds, or school textbooks etc.

${ }^{11}$ Specifically, this is defined for the county as the logarithm of the 5 to 17 year old population in 2000 minus the logarithm of the 5 to 17 year old population in 1990, all divided by the logarithm of total population in 2000 minus the logarithm of total population in 1990.

${ }^{12}$ We thank David Figlio for the tax and expenditure limit indicators and Margaret Raymond for the accountability indicators. See data appendix table 2 for a list of which states have tax and expenditure limits and which states have accountability measures.
} 
more likely to adopt these food policies that generate discretionary funds. Similarly, we expect $\gamma_{4}$ to be positive, since schools in states with accountability laws may be under pressure to meet certain performance criteria. These criteria generally take the form of standardized tests scores (not measures of students' physical health), and thus schools may divert resources toward core academics and away from other programs. In order to preserve optional programs, schools may come up with creative ways to raise additional funds, including sales of snack foods and beverages.

The tax and expenditure limit indicator and the fraction of school revenues that come from the state are meant to capture how difficult it may be for schools to raise additional funds for valued programs. It may be more difficult for schools to raise funds through traditional means in a state with strict tax and expenditure limits, thus we expect $\gamma_{3}$ to be positive.

Similarly, each state has a funding formula that specifies how much of a school district's funds will come from the state. ${ }^{13}$ Within state, this fraction tends to be negatively related with fiscal capacity. However, there is also a good deal of variation at the state level. ${ }^{14}$ Across states, more school funding coming from the state may reflect more difficulty for local school districts to unilaterally decide to raise funds. This difficulty may simply be political - that is the district relies more on the state because it is difficult to pass higher local property tax rates. Alternatively, the difficulty may stem from characteristics of the local tax base. For example, localities with a large commercial base may be in a better position to raise funds because the businesses pay local taxes, but do not increase the number of children requiring education.

\footnotetext{
${ }^{13}$ The most common approach is the foundation program, but other methods include a flat grant, percentage equalizing, guaranteed tax base or guaranteed equal yield programs (Sielke and Holmes).

${ }^{14}$ In our SHPPS data, the average ranges from 32 percent in South Carolina to 75 percent in New Mexico, while in the NLSY97 data, New Hampshire has the minimum at 11 percent, and Hawaii the maximum at 88 percent.
} 
Finally, we control for region of the country $(\boldsymbol{R})$ in both the first and second stage to control for additional factors that may influence school food policy decisions and children's obesity.

Having obtained estimates of $\gamma_{0}, \gamma_{1}, \gamma_{2}, \gamma_{3}, \gamma_{4}$ and $\gamma_{5}$ using the SHPSS/NCES county-level data, we then use these estimates to predict food policies in individual-level data from the NLSY97. Because the independent variables in the first stage vary only at the county and state level, and since we know the county of residence for the NLSY97, we can append the appropriate fiscal, legal, and population change variables to the individual data and create predicted food policies based on the first stage estimates. We can then estimate the effect of predicted food policy on individual weight status, controlling for additional covariates.

To do so, we use a model of the following form:

$$
\ln (\text { bmi })_{i}=\alpha+\beta_{1} \text { predicted policy } c+\beta_{2} \boldsymbol{X}_{i}+\beta_{3} \boldsymbol{F}_{i}+\beta_{4} \boldsymbol{R}_{\mathrm{i}}+\varepsilon_{i}
$$

where $\ln (\mathrm{bmi})$ is the log of the individual's Body Mass Index; $\boldsymbol{X}$ is a set of individual-level covariates, including age, race, sex and cigarette use; $\boldsymbol{F}$ is a set of family background covariates, including family income, mother's and father's education and the log of the responding parent's BMI; and $\boldsymbol{R}$ is a set of region dummies. All of the data used in both stages are described in more detail in the Data Appendix. Finally, we adjust the standard errors for arbitrary forms of heteroskedasticity and within county correlation. In addition, we adjust the standard errors for the fact that the policy variables are estimated (see Murphy and Topel, 1985).

Our maintained assumption is that the variables used in the first stage to estimate the fraction of schools in a county with these three food policies - aside from region - do not directly affect individual's BMI. It seems quite plausible that individuals' energy intake and expenditure is not governed by state tax policy. Nonetheless, one might be concerned that there are characteristics of individuals or places that affect BMI that are correlated with our predicted 
school food policy variables. For example, one might be concerned that socioeconomic status, which research shows is correlated with obesity, is also correlated with our predicted food policy. We do several things to allay our worries on this score. First, we include a rich set of controls for socioeconomic status in the second stage. If the variation in policy generated from the first stage were coming from underlying variation in socioeconomic status, we would expect the estimated impact of the policies in the second stage to be very sensitive to whether or not we control for these characteristics. In addition, because we have more than one excluded instrument, we can construct overidentification tests for the null hypothesis that our instruments are exogenous. In all cases, we fail to reject the null hypothesis.

Finally, one might worry that there are unobserved characteristics at the state level that drive both food policies and adolescent BMI. In this case, one would want to control for state fixed effects in the second stage. However, we cannot do this because much of our variation in our policy variables is at the state level. In order to see whether we are merely picking up state differences, we estimated a set of "placebo" results where we estimated the first stage with a full set of state dummies, but excluded these from the second stage. If this had given us similar results to those reported below, we would have been concerned that our instruments were working through unobserved state differences, as opposed to through the budgetary pressures posited above. However, we find no effect of the food policy variables when predicted from state fixed effects. $^{15}$

\section{B. The Relationship between School Food Policies and Finances}

The results from estimating the first stages described by equation (1) above are shown in Table 2. The first column gives the means of the independent variables while the first row gives the means for the dependent variables across the 180 counties in the SHPPS. First, note that all 
of the estimated effects for the instruments are of the predicted sign. Since higher values for each independent variable represents a higher level of local budgetary pressure, our hypothesis predicts a positive coefficient. For both junk food and pouring rights, the fraction of total revenues that come from the state is significantly positive. For both junk food and school advertising, the tax and expenditure limit indicator is significant. Thus, at least one of the variables is significant in each case. The F-statistics reported at the bottom of the table indicate that the excluded instruments combined are significant for both junk food and pouring rights, but not significant at conventional levels for school advertising. Note that the standard errors are corrected for arbitrary forms of heteroskedasticity and within state correlation. ${ }^{16}$

\section{The Effect of Predicted School Policies on Obesity}

The results from estimating equation (2) described above are reported in Table 3. Columns (1) - (2) use junk food availability as the predicted policy, columns (3) - (4) use pouring rights, and columns (5) - (6) use soda or snack food ads. For each policy, the first model includes no covariates other than region dummies, while the second estimates equation (2) in full. The first thing to note is that the additional covariates have very little impact on the key policy coefficient. This result is not really unexpected, given that the policy variable is predicted based on exogenous fiscal policy measures that are unlikely to be highly correlated with the individual's demographic background. We present the p-value for an overidentification test with the null hypothesis that the instruments are exogenous. We fail to reject the null hypothesis in all cases (although we come somewhat close in the case of advertisements).

\footnotetext{
${ }^{15}$ This is continues to be true if we also include the variables that vary at the county level in the first stage.

${ }^{16}$ In this stage, the data are already at the county level, but we allow for within state correlation. In the second stage, the data is at the individual level, but we allow for within-county correlations, since the predicted policy will only vary at the county level.
} 
Focusing on the results that include the full set of controls, the column (2) estimates imply that a 10 percentage point increase in the proportion of schools in a county that make junk food available to their students, is correlated with a nearly 1 percent $(0.90 \%)$ increase in students' BMI. The results are smaller for the fraction of schools with pouring rights contracts, and marginally significant. The results for the fraction of schools that allow advertising are smaller still, and are insignificant. This result suggests that it is the actual availability of potentially unhealthful foods that affects adolescents' weight, as opposed to the type of contract the schools sign with food purveyors or the advertising they allow.

Turning to the estimates for the other variables, in all cases the point estimates imply that females and those from richer families have lower BMIs, while blacks and Hispanics have higher BMIs. ${ }^{17}$ Perhaps the most interesting control variable is the parental BMI, which implies an elasticity of 0.22 between child and parent. ${ }^{18}$

For a nonrandom subset of the data, we can match the county-level policy from the SHPPS data to the individual-level data from the NLSY97. ${ }^{19}$ There are 1007 individuals, living in 78 different counties for which we can perform this match. As a check on our two-sample procedure, we estimate several models with these matched data. First, we estimate equation (2) using OLS, where "predicted policy" is no longer predicted, but is the matched county policy. We then estimate the same model by IV, using the state and county legal, finance, and population change variables from equation (1) as the excluded instruments. Finally, we estimate the two-sample procedure on the smaller matched sample and compare these results with the

\footnotetext{
${ }^{17}$ Note that in the NHANES females are not less likely to be obese, so our finding may be a reflection of sexspecific errors in the NLSY97 self-reported height and weight

${ }^{18}$ Note that 83 percent of the time this parent is the biological mother, while $11 \%$ of the time it is the biological father. Another 3\% are a related female guardians and the rest are mainly step-mothers. If we limit the sample to only those for whom the responding parent is the biological mother, we get nearly identical results.

${ }^{19}$ Data appendix table 1 shows summary statistics for all the variables in the overall and matched samples of the NLSY97. The means are very similar for the 2 samples, especially for BMI. The main differences seems to be that
} 
actual IV results. The first stage results are reported in appendix table 1. The second stage results are reported in appendix table 2.

The point estimates from the two-sample and IV models are very similar to each other, and to those in Table 3. However, the smaller sample size results in relatively large standard errors, such that none are significant at conventional levels. For junk food, recall that in table 3 the estimated effect was 0.090 , with a standard error of 0.045 . The IV model in the matched sample produces an estimated effect of 0.140 , but with a standard error of 0.084 . Standard errors are even larger with the two-sample method. The matched sample two-step procedure yields a lightly larger estimate of 0.160 , with a standard error of 0.117 . Based on the matched sample, we conclude that our two-sample method is producing estimates similar to what would be obtained from a more standard IV model, but that we pay a price with slightly larger standard errors.

A perhaps more interesting comparison is that between the OLS and IV estimates for the matched sample. The OLS point estimates are uniformly smaller (between 0.019 and 0.034 ) than the IV or two-sample estimates, and not significantly different from zero. The implication, then, is that the OLS estimates are biased downward. One possibility is that the types of areas with more junk food, pouring rights contracts and snack food ads are the types of areas for which other unobservables would tend to produce leaner adolescents. ${ }^{20}$ For example, suppose that parental demand for better academic achievement, more extracurricular activities (or both) is behind schools raising additional funds through food policies. These same demanding parents may provide more healthful foods and exercise opportunities in their homes than less involved

\footnotetext{
there are more respondents in the West and fewer in the South in the matched sample.

${ }^{20}$ Hausman tests for whether the policies are exogenous reject exogeneity in the cases of junk food availability and snack food and beverage advertising.
} 
parents, resulting in a negative bias in the OLS estimates. Alternatively, simple attenuation bias due to measurement error in the policy variable may explain the larger IV estimates.

\section{The Interaction of School Food Policy and Genetics (or Family Susceptibility)}

The overall results can be summarized as implying that a 10 percentage point increase in the proportion of schools with junk food is correlated with about a 1 percent higher BMI for the average student. There are smaller and often insignificant effects for the other food policies examined here. One should not read the estimates in table 3, however, as implying that every student exposed to such food policies will increase their BMI by 1 percent. A fairly large literature exists documenting a strong genetic component to weight (e.g. Grilo and Pogue-Geile, 1991). At the same time, the increases in obesity seen over the past 20 years clearly cannot be attributed to changes in the gene pool. Thus, it seems reasonable to expect that some portion of the population has a genetic susceptibility for weight gain, and under certain conditions will, in fact, be more likely to gain weight. The idea of a genetic predisposition for weight gain is at the heart of the theory of the "thrifty gene" by pioneering geneticist James Neel (Neel, 1962). In studying the Pima Indians, he theorized that in difficult times, when many Pima died of starvation, the survivors had a genetic advantage in storing energy as fat. This "thrifty gene" was then passed on to future generations. In modern times, when the Pima live in an environment of relative caloric abundance, this genetic predisposition toward more efficient fat storage results in high rates of obesity.

It is with this idea of the interaction between nature and nurture in mind that we estimate equation (2) separately by parental weight status. Table 4 shows results separately for those whose responding parent is normal weight $(\mathrm{BMI}<25)$, overweight $(25<=\mathrm{BMI}<30)$, and obese 
$(\mathrm{BMI}>=30)$. For completeness we show the results for all the policies, although only those for junk food availability are significantly different from zero. While it is difficult to get precise estimates for these smaller subgroups (especially the obese parent group), the effect of junk food on adolescents whose parents are overweight is statistically significantly different from those whose parents are normal weight. ${ }^{21}$ For the students with a normal weight parent, there is essentially no effect of junk food (or any of the other policies) on their BMI. However, for those whose parent is overweight, a 10 percentage point increase in the proportion of schools with junk food availability increases their BMI by over 2 percent (2.21\%). The estimates for the other school food policies are less precise. However, in each case, the point estimates for those with overweight parents are much larger. Thus, there is evidence that for those who are genetically susceptible to weight gain, the school environment may play an important role. At the same time, for the 44 percent of students with normal weight parents, the school food policy makes no difference at all.

\section{Summary and Avenues for Future Research}

Researchers and public health officials are currently at a loss to explain the rapid rise in weight problems among children and adolescents. While it is clear that weight gain is attributable to taking in more energy than one expends, it is unclear what has upset the balance between energy intake and expenditure in recent decades. Thus, it is important to consider the environmental factors that may affect either the intake or expenditure of energy. In looking at adult obesity, Cutler, Glaeser and Shapiro (2003) point to technological innovations over recent decades that have lowered the time cost of food consumption. The result of these lower time costs is increased caloric intake. In the adolescent context, the increasing number of schools

\footnotetext{
${ }^{21} \mathrm{We}$ reject that the estimates are the same with a p-value of 0.047 .
} 
with vending machines provided for student use might be considered to be an example of this type of technological innovation.

Perhaps not surprisingly, then, policy makers have begun to point to school food policies as potentially important contributors to student weight problems. Although no solid evidence currently exists on this link, several large school districts have banned or severely restricted the availability of sodas and snack foods in schools. This paper takes a first step at assessing the effect of school food policies on adolescent weight.

We find that schools that are under financial pressure (as captured by our available data) are more likely to make junk food available to their students, have pouring rights contracts, and allow food and beverage advertising to students. We use measures that capture financial pressure to predict the fraction of schools in a county with these particular food policies, and then estimate the effect of the fraction of schools in a county with these food policies on adolescent BMI. This two-step method is meant to give us variation in school food policies that is correlated with schools' fiscal capacity, but not directly correlated with unobservable factors linked to the prevalence of unhealthy weights among the students. We find fairly robust evidence that an increase in the proportion of schools making junk food available to students is linked to an increase in students' BMI. Our results for the other school policies, pouring rights contracts and food and beverage advertisements, are smaller and less precise. The results suggest that a 10 point increase in the percentage of schools in a county that allow their students access to junk food leads to a 1 percent increase in students' BMI. Since average weight for adolescents in this sample is about 148 pounds, this translates into about 1.5 extra pounds per 10 percentage point increase in availability. 
This result, however, masks large differences between those who we would think have a family or genetic susceptibility to obesity and those who do not. For those students with normal weight parents, there is no effect of school food policies on their BMI. However, for students with overweight parents, the effect of a 10 percentage point increase in schools making junk food available to students is a greater than 2 percent increase in students' BMI. Since the average weight among adolescents with an overweight parent is 166 pounds, this translates into 3.3 extra pounds per 10 percentage point increase in junk food availability. This is consistent with the facts of the obesity epidemic: people in the right hand tail of the BMI distribution have been putting on weight more rapidly than those in the rest of the distribution. As mentioned earlier, there appears to be a portion of the population that is susceptible to obesity, and the current environment is one that promotes their disease. For students with this susceptibility, these school food policies appear to be part of the environment that encourages their propensity to gain weight.

Currently, policy makers are acting to reduce access to junk food and soda pop in a number of school districts around the country, with the express purpose of curbing adolescent obesity. We can do a rough "back of the envelope calculation" to bound how much of the recent increase in adolescent BMI may be attributed to the increased availability of such foods in schools over the last decade. ${ }^{22}$ Data from the 1994 and 2000 waves of the SHPPS show that the percentage of high schools giving their students access to vending machines increased from 88 percent to 96 percent, or by 8 percentage points. Our estimates reported here imply that an 8 percentage point increase in the number of schools allowing students access to junk food would

\footnotetext{
${ }^{22}$ This calculation uses the authors' calculations from the NHANES and SHPPS data reported in Anderson, Butcher, and Levine (2003a) tables 1 and 6.
} 
translate into about a 0.8 percent increase in BMI on average. ${ }^{23}$ Data from the NHANES show that BMI among 12-19 year olds increased by about 3.5 percent between the 1988-1994 and the 1999-2000 interviews. Roughly then, about a fifth (22\%) of the average increase in adolescent BMI could be attributed to the increase in availability of junk food in schools. While we would like to do a similar calculation for those whose parents are overweight, we do not have information on parental BMI in the NHANES. ${ }^{24}$

Thus, policy makers may be disappointed if they are expecting reductions in soda pop availability in schools, for example, to be a "magic bullet" in the fight against adolescent obesity. Future research might fruitfully examine the impact of these changes on the ground in New York and Los Angeles and other school districts where they have banned certain "junk foods."

Evaluations of the impact will need to consider which products are allowed to substitute for soda pop and "junk" foods (for example, fruit juices, which are allowed under most of these revised school policies, often have just as many calories as soda pop). In addition, evaluators should take into account the benefits of existing school food policies. If it is the case that existing food policies help generate funds for valuable programs, then the benefit (potentially to all students) needs to be weighed against the health costs borne by the fraction of students with a susceptibility to obesity.

\footnotetext{
${ }^{23}$ Note that our estimates are for access to junk food and not access to a vending machine. The 1994 and 2000 waves of the SHPPs are not identical and we do not know what fraction of schools gave access to junk food in 1994. One should keep in mind that access to junk food and access to a vending machine are not identical - students may obtain junk food from places other than vending machines and vending machines may sell things that are not "junk." In particular, only about 75 percent of schools give students access to foods we have defined as "junk food" in 2000, while 96 percent give students access to a vending machine.

${ }^{24}$ One should not assume that just because we estimate the impact of junk food availability on BMI to be larger for this group that increases in vending machines are responsible for a larger proportion of the increase in BMI among this group - the percentage increase in BMI (the denominator in this calculation) is likely larger for this group as well.
} 


\section{References}

Anderson, Patricia M., Kristin F. Butcher and Phillip B. Levine. "Economic Perspectives on Childhood Obesity," Economic Perspectives, 3Q, (2003a): 30 - 48.

Anderson, Patricia M., Kristin F. Butcher and Phillip B. Levine. "Maternal Employment and Overweight Children," Journal of Health Economics, 22, (May 2003b): 477 - 504.

Angrist, Joshua and Alan Krueger. "The Effect of Age at School Entry on Educational Attainment: An Application of Instrumental Variables with Moments from Two Samples.” Journal of the American Statistical Association. Vol 87, June 199: pp. 328336.

Angrist, Joshua and Alan Krueger. "Split-Sample Instrumental Variables Estimates of the Return to Schooling." Journal of Business and Economic Statistics. Vol 13, April 1995: pp. 225235.

Carter, Robert Colin. "The Impact of Public Schools on Childhood Obesity." JAMA. November 6, 2002: p. 2180.

Cawley, John. "Rational Addiction, the Consumption of Calories, and Body Weight." Ph.D. dissertation. U. of Chicago, 1999.

Cullen, Karen Weber, Jill Eagan, Tom Baranowski, Emiel Owens and Carl de Moor. "Effect of a la carte and snack bar foods at school on children's lunchtime intake of fruits and vegetables." Journal of the American Dietetic Association. December 2000: pp. 14821486.

Cutler, David M., Edward L. Glaeser, and Jesse M. Shapiro. "Why Have Americans Become More Obese?" Journal of Economic Perspectives, 17(3) Summer 2003: 93 - 118.

DD Marketing. Educational Division Corporate Web Page. Accessed March 3, 2003 at http://www.ddmktg.com/div-edu.html

Dietz, William H. and Mary C. Bellizzi. "Introduction: The Use of Body Mass Index to Assess Obesity in Children. American Journal of Clinical Nutrition. Vol. 70 (suppl, 1999). pp. $123 \mathrm{~S}-125 \mathrm{~S}$.

Downes, Thomas A. and David N. Figlio. "Do Tax and Expenditure Limits Provide a Free Lunch? Evidence on the Links Between Limits and Public Sector Service Quality." National Tax Journal, March 1999, pp. 113-128.

Ebbeling, Cara B., Dorota B. Pawlak, David S. Ludwig, "Childhood Obesity: Public-health Crisis, Common Sense Cure,” The Lancet, vol 360, no. 9331, August 10, 2002, pp. 473482. 
Freeman, J. V, and C. Power, and B. Rodgers. "Weight-for-Height Indices of Adiposity: Relationships with Height in Childhood and Early Adult Life." International Journal of Epidemiology. Vol. 24, No. 5 (October 1995), pp. 970-976.

Fried, Ellen J. and Marion Nestle. "The Growing Political Movement Against Soft Drinks in Schools.” JAMA. November 6, 2002: p. 2181.

Grilo, Carlos M. and Michael F. Pogue-Geile. "The Nature of Environmental Influences on Weight and Obesity: A Behavioral Genetic Analysis." Psychological Bulletin. Vol. 110, No. 3, (November 1991), pp. 520-537.

Hanushek, Eric A. and Margaret E. Raymond. "Improving Education Quality: How Best to Evaluate Our Schools?" paper prepared for Federal Reserve Bank of Boston conference June 19-21, 2002.

Kubik, Martha Y., Leslie A. Lytle, Peter J. Hannan, Cheryl L. Perry and Mary Story. "The Association of the School Food Environment with Dietary Behaviors of Young Adolescents." American Journal of Public Health. Vol 93, No. 7, July 2003, pp. 1168 1173.

Ludwig, David S., Karen E. Peterson, Steven L. Gortmaker. "Relation between consumption of sugar-sweetened drinks and childhood obesity: a prospective, observational analysis." The Lancet. February 17, 2001: pp. 505-508.

Murphy, Kevin M. and Robert H. Topel. "Estimation and Inference in Two-Step Econometric Models," Journal of Business and Economic Statistics, Vol. 3, No. 4 (October 1985), pp. 370-379.

Nakamura, David. "Schools Hooked on Junk Food." Washington Post. February 27, 2001: pg A01.

Neel, James V. (1962) Diabetes mellitus: a "thrifty" genotype rendered detrimental by "progress"? American Journal of Human Genetics 14:353 362.

Odgen, Cynthia L., Katherine M. Flegal, Margaret D. Carroll, Clifford L. Johnson. "Prevalence and Trends in Overweight Among US Children and Adolescents, 1999-2000." JAMA. October 9, 2002: pp. 1728-1732.

Pateman, Beth Collins, Patricia McKinney, Laura Kann and Meg Leavy Small. "School Food Service.” The Journal of School Health. October 1995: pp. 327-332.

Perez-Pena, Richard. "Obesity on Rise in New York Public Schools." The New York Times. July 9, 2003. 
Schwimmer, Jeffrey B., Tasha M. Burwinkle, James W. Varnie, "Health-Related Quality of Live of Severely Obese Children and Adolescents," Journal of the American Medical Association, vol. 289, no. 14, 2003, pp.1813-1819.

Sielke, Catherine C. and C. Thomas Holmes. "Overview of Approaches to State School Funding." Summary discussion of Public School Finance Programs in the United States and Canada at http://www.ed.sc.edu/aefa/reports/ch1.pdf.

Wecshler, Howell, Nancy D. Brener, Sarah Kuester, Clare Miller. "Food Service and Foods and Beverages Available at School: Results from the School Health Policies and Programs Study 2000.” The Journal of School Health. September 2001: pp. 313-324.

Whitaker, Robert C., Jeffrey A. Wright, Margaret S. Pepe, Kristy D. Seidel, and William H. Dietz. "Predicting Obesity in Young Adulthood from Childhood and Parental Obesity." The New England Journal of Medicine. Vol. 337, No. 13 (September 25, 1997), pages 869-873. 
Table 1: Comparison of BMI and Obesity Across Data Sets

\begin{tabular}{|c|c|c|c|c|}
\hline Age & $\begin{array}{c}\text { NHANES } \\
1999-2000 \\
14-20 \\
\end{array}$ & $\begin{array}{c}\text { NLSY97 } \\
1999 \text { Panel } \\
14-20 \\
\end{array}$ & $\begin{array}{c}\text { NHANES } \\
1999-2000 \\
\text { Women 32-67 }\end{array}$ & $\begin{array}{c}\text { Parent's of } \\
\text { NLSY97 } \\
\text { 1999 Panel } \\
\text { 32-67 }\end{array}$ \\
\hline BMI Mean & $\begin{array}{l}24.07 \\
(5.47)\end{array}$ & $\begin{array}{l}22.99 \\
(4.63)\end{array}$ & $\begin{array}{l}28.52 \\
(7.25)\end{array}$ & $\begin{array}{l}26.53 \\
(5.87)\end{array}$ \\
\hline BMI Median & 22.77 & 21.95 & 27.55 & 25.10 \\
\hline $\begin{array}{l}\text { BMI 95 }{ }^{\text {th }} \\
\text { Percentile }\end{array}$ & 34.8 & 31.93 & 41.93 & 37.76 \\
\hline $\begin{array}{l}\text { Fraction } \\
\text { Obese }\end{array}$ & $\begin{array}{c}0.152 \\
(0.359)\end{array}$ & $\begin{array}{c}0.109 \\
(0.312)\end{array}$ & $\begin{array}{c}0.373 \\
(0.484)\end{array}$ & $\begin{array}{c}0.228 \\
(0.419)\end{array}$ \\
\hline
\end{tabular}

\begin{tabular}{ccccc}
\hline No. of Obs. & 1742 & 3482 & 1293 & 3482 \\
\hline Notes: Summary statistics and standard deviations (in parentheses) from authors' calculations
\end{tabular} from the 1999-2000 National Health and Nutrition Examination Survey (NHANES) and the 1999 panel of the National Longitudinal Survey of Youth 1997 cohort. In the NLSY97 data on parent's BMI is for the responding parent: $83 \%$ are the biological mothers, $10 \%$ are the biological fathers, $3 \%$ are related female guardians, $2 \%$ are stepmothers. To come close to matching this, the NHANES data are for women in the relevant age range. The data are weighted using sample weights. 
Table 2: First Stage Predictions of Food Policies

\begin{tabular}{lcccc}
\hline & $\begin{array}{c}\text { Mean of } \\
\text { Independent } \\
\text { Variable } \\
\text { (Std. Dev.) }\end{array}$ & $\begin{array}{c}\text { Fraction of } \\
\text { Schools in } \\
\text { County in which } \\
\text { can Purchase } \\
\text { Junk Food }\end{array}$ & $\begin{array}{c}\text { Fraction of } \\
\text { Schools in } \\
\text { County with } \\
\text { "Pouring Rights" } \\
\text { Contracts }\end{array}$ & $\begin{array}{c}\text { Fraction of } \\
\text { Schools in } \\
\text { County that } \\
\text { allow Food Ads. } \\
\text { at School }\end{array}$ \\
\hline $\begin{array}{l}\text { Mean of Dep. Var. } \\
\text { (Std. Dev.) }\end{array}$ & 0.748 & 0.671 & 0.441 \\
Share of Total Rev. from & 0.495 & $(0.352)$ & $(0.405)$ & $(0.406)$ \\
State Sources & $(0.142)$ & $(0.157)$ & 0.502 & 0.371 \\
State has Tax and & 0.472 & 0.113 & $(0.239)$ & $(0.241)$ \\
Expenditure Limits & $(0.501)$ & $(0.061$ & 0.077 & 0.119 \\
1990 to 2000 Relative & 0.939 & 0.0003 & $-0.059)$ & $(0.061)$ \\
Growth Rate in County & $(10.18)$ & $(0.0016)$ & $(0.0025)$ & 0.0020 \\
Pop. Aged 5-17 & & 0.070 & $0.0020)$ \\
State has School & 0.856 & $(0.100)$ & $(0.073)$ & -0.042 \\
Accountability Rules & $(0.353)$ & 0.102 & -0.061 & $(0.102)$ \\
Northeast & 0.156 & $(0.089)$ & $(0.139)$ & -0.102 \\
Midwest & $(0.363)$ & -0.156 & 0.212 & $0.122)$ \\
South & 0.261 & $(0.068)$ & $(0.071)$ & $(0.095)$ \\
Constant & $(0.440)$ & 0.047 & 0.140 & 0.233 \\
& 0.372 & $(0.071)$ & $(0.075)$ & $(0.077)$ \\
\hline No. of Observations & $(0.485)$ & 0.469 & 0.193 & 0.131 \\
R-squared & & $(0.121)$ & $(0.151)$ & $(0.167)$ \\
\hline F-statistic for excluded & 180 & 180 & 179 & 180 \\
instruments & & 0.1334 & 0.1058 & 0.1344 \\
p-value for excluded & & 3.88 & 4.91 & 2.04 \\
instruments & & 0.0094 & 0.0026 & 0.1069 \\
\hline
\end{tabular}

Notes: Dependent variables come from public middle and high schools sampled in the 2000 wave of the School Health Policy and Programs Study (SHPPS). SHPPS school weights are used to aggregate the data to the county level. Revenues come from the NCES Common Core Data for each district. District enrollment is used to aggregate the data to the county level. Growth in county population of children aged 5-17 relative to total county population growth from 1990 to 2000 comes from the U.S. Census. See data appendix for more details. See data appendix table 2 for information on which states have property tax revenue limits and which have accountability laws. "Junk Food Available" means that the students can buy chocolate, candy, cakes, ice cream or salty snacks (that are not fat free) from a machine or school store. "Pouring Rights" contracts means the school has agreed to sell one brand of soft drinks. "Soda or Snack Food Advertisements" means that advertisements are allowed at least at one type of school related activity or in one or more places at the school - for example, on a school bus, at a school sporting event, on school grounds, or school textbooks etc. Standard errors (in parentheses) are adjusted for arbitrary correlation within the state. 
Table 3: Estimated Effect of Predicted School Food Policies on Ln(BMI)

Public School Students in the NLSY 1997

\begin{tabular}{|c|c|c|c|c|c|c|}
\hline & $\begin{array}{c}\text { Dep Var: } \\
\text { Ln(BMI) } \\
\text { Policy: } \\
\text { Junk Food } \\
\text { Available } \\
\text { (1) }\end{array}$ & $\begin{array}{c}\text { Dep Var: } \\
\text { Ln(BMI) } \\
\text { Policy: } \\
\text { Junk Food } \\
\text { Available } \\
\text { (2) }\end{array}$ & $\begin{array}{c}\text { Dep Var: } \\
\text { Ln(BMI) } \\
\text { Policy: } \\
\text { Pouring } \\
\text { Rights } \\
\text { (3) }\end{array}$ & $\begin{array}{c}\text { Dep Var: } \\
\text { Ln(BMI) } \\
\text { Policy: } \\
\text { Pouring } \\
\text { Rights } \\
\text { (4) }\end{array}$ & $\begin{array}{c}\text { Dep Var: } \\
\text { Ln(BMI) } \\
\text { Policy: } \\
\text { Beverage } \\
\text { or Snack } \\
\text { Food Ads. } \\
(5)\end{array}$ & $\begin{array}{c}\text { Dep Var: } \\
\text { Ln(BMI) } \\
\text { Policy: } \\
\text { Beverage } \\
\text { or Snack } \\
\text { Food Ads. } \\
(6)\end{array}$ \\
\hline $\begin{array}{c}\text { Predicted } \\
\text { Policy }\end{array}$ & $\begin{array}{c}0.106 \\
(0.052)\end{array}$ & $\begin{array}{c}0.090 \\
(0.045)\end{array}$ & $\begin{array}{c}0.099 \\
(0.052)\end{array}$ & $\begin{array}{c}0.075 \\
(0.042)\end{array}$ & $\begin{array}{c}0.041 \\
(0.041)\end{array}$ & $\begin{array}{c}0.038 \\
(0.033)\end{array}$ \\
\hline $\begin{array}{l}\text { African } \\
\text { American } \\
\text { Hispanic }\end{array}$ & & $\begin{array}{c}0.034 \\
(0.012) \\
0.016 \\
(0.011)\end{array}$ & & $\begin{array}{c}0.035 \\
(0.012) \\
0.017 \\
(0.011)\end{array}$ & & $\begin{array}{c}0.034 \\
(0.012) \\
0.016 \\
(0.011)\end{array}$ \\
\hline Female & & $\begin{array}{l}-0.027 \\
(0.007)\end{array}$ & & $\begin{array}{l}-0.027 \\
(0.007)\end{array}$ & & $\begin{array}{l}-0.027 \\
(0.007)\end{array}$ \\
\hline Age & & $\begin{array}{c}0.019 \\
(0.003)\end{array}$ & & $\begin{array}{c}0.019 \\
(0.003)\end{array}$ & & $\begin{array}{c}0.019 \\
(0.003)\end{array}$ \\
\hline $\begin{array}{l}\text { Family Inc. } \\
\text { (in 100Ks) } \\
\text { Ln(Parent's } \\
\text { BMI) }\end{array}$ & & $\begin{array}{c}-0.015 \\
(0.009) \\
0.221 \\
(0.018) \\
\end{array}$ & & $\begin{array}{c}-0.014 \\
(0.009) \\
0.221 \\
(0.018) \\
\end{array}$ & & $\begin{array}{c}-0.014 \\
(0.009) \\
0.221 \\
(0.018) \\
\end{array}$ \\
\hline $\begin{array}{l}\text { No. of Obs } \\
\text { R-squared } \\
\text { p-value for } \\
\text { Overid. test } \\
\left(\chi^{2} \sim 3 \text { d.f. }\right)\end{array}$ & $\begin{array}{c}3482 \\
0.0037\end{array}$ & $\begin{array}{c}3482 \\
0.1078 \\
0.554\end{array}$ & $\begin{array}{c}3482 \\
0.0040\end{array}$ & $\begin{array}{c}3482 \\
0.1074 \\
0.425\end{array}$ & $\begin{array}{c}3482 \\
0.0022\end{array}$ & $\begin{array}{c}3482 \\
0.1065 \\
0.116\end{array}$ \\
\hline $\begin{array}{l}\text { Mean (SD) of } \\
\text { Pred. Policy } \\
\text { Mean (SD) } \\
\text { of Dep. Var. }\end{array}$ & $\begin{array}{c}0.758 \\
(0.119) \\
3.117 \\
(0.183)\end{array}$ & $\begin{array}{c}0.759 \\
(0.119) \\
3.117 \\
(0.183)\end{array}$ & $\begin{array}{c}0.684 \\
(0.137) \\
3.117 \\
(0.183)\end{array}$ & $\begin{array}{c}0.684 \\
(0.137) \\
3.117 \\
(0.183)\end{array}$ & $\begin{array}{c}0.438 \\
(0.168) \\
3.117 \\
(0.183)\end{array}$ & $\begin{array}{c}0.438 \\
(0.168) \\
3.117 \\
(0.183)\end{array}$ \\
\hline
\end{tabular}

Notes: Data are from the 1999 panel of the NLSY97. The sample includes individuals who attended public schools during the 1999-2000 school year. In both sets of models we include dummies for region (Northeast, Midwest, and South), and a constant. In the second set of models we control for whether the individual reports smoking since the last interview, years of education of the biological mother and father, and dummy variables indicating if this information is missing. Log of Parent's BMI is for the responding parent (see notes to table 1). Table 2 shows the model used to create the predicted policy. The results here are from two sample estimation. The standard errors (in parentheses) are corrected both for arbitrary correlation within county, and for the fact that the policy variable is estimated. The regressions are weighted with NLSY sample weights. The overidentification test is for the null hypothesis that the excluded instruments are exogenous. In all cases, we fail to reject exogeneity. 
Table 4: Estimated Effect of Predicted School Food Policies on Ln(BMI)

Public School Students in the NLSY 1997, by Responding Parent's Weight Status

\begin{tabular}{lccc}
\hline Policy Variable & $\begin{array}{c}\text { Under to Normal } \\
\text { Weight }\end{array}$ & $\begin{array}{c}\text { Overweight } \\
\text { (Not Obese) }\end{array}$ & Obese \\
\hline Junk Food Avail. & 0.014 & 0.221 & 0.079 \\
& $(0.052)$ & $(0.090)$ & $(0.110)$ \\
R-Squared & 0.0645 & 0.0769 & 0.0360 \\
& & & \\
Pouring Rights & 0.024 & 0.157 & 0.076 \\
& $(0.045)$ & $(0.081)$ & $(0.098)$ \\
R-Squared & 0.0646 & 0.0737 & 0.0361 \\
& & & \\
Any Ads & -0.009 & 0.092 & 0.0004 \\
& $(0.053)$ & $(0.065)$ & $0.049)$ \\
R-Squared & 0.0644 & 0.0718 & 0.0351 \\
& & & 906 \\
\hline No. of Obs. & 1533 & 1043 & 3.194 \\
Mean (SD) of & 3.075 & 3.128 & $(0.212)$ \\
Dependent Var. & $(0.154)$ & $(0.180)$ & . \\
\hline
\end{tabular}

Notes: Data are from the 1999 panel of the NLSY97. The sample includes individuals who attended public schools during the 1999-2000 school year. All models include the same set of controls variables as columns 2,4 , and 6 in table 3 . Table 2 shows the model used to create the predicted policy. The results here are from two sample estimation. The standard errors (in parentheses) are corrected both for arbitrary correlation within county, and for the fact that the policy variable is estimated. The regressions are weighted with NLSY sample weights. Under to normal weight is defined as a $\mathrm{BMI}<25$, overweight (not obese) is defined as a $25<=\mathrm{BMI}<30$ and obese is defined as a BMI $>=30$. The responding parent is the biological mother $83 \%$ of the time, and the biological father $10 \%$ of the time, while $3 \%$ are related female guardians and $2 \%$ are stepmothers. 
Appendix Table 1: First Stage Results for the "Matched" Sample.

Percent of Schools in the County with given Food Policy

\begin{tabular}{|c|c|c|c|}
\hline & $\begin{array}{c}(1) \\
\text { Junk Food Available }\end{array}$ & $\begin{array}{c}(2) \\
\text { Pouring Rights }\end{array}$ & $\begin{array}{c}\text { (3) } \\
\text { Any Beverage or Snack } \\
\text { Food Ads }\end{array}$ \\
\hline $\begin{array}{l}\text { Mean of Dependent Variable } \\
\text { (Std. Dev.) }\end{array}$ & $\begin{array}{c}0.816 \\
(0.277)\end{array}$ & $\begin{array}{c}0.649 \\
(0.385)\end{array}$ & $\begin{array}{c}0.427 \\
(0.376)\end{array}$ \\
\hline $\begin{array}{l}\text { Share of Total Revenues } \\
\text { From State Sources }\end{array}$ & $\begin{array}{l}-0.188 \\
(0.214)\end{array}$ & $\begin{array}{c}0.570 \\
(0.415)\end{array}$ & $\begin{array}{c}0.311 \\
(0.377)\end{array}$ \\
\hline $\begin{array}{l}\text { State has Tax and } \\
\text { Expenditure Limits }\end{array}$ & $\begin{array}{c}0.093 \\
(0.077)\end{array}$ & $\begin{array}{c}0.023 \\
(0.118)\end{array}$ & $\begin{array}{l}-0.045 \\
(0.094)\end{array}$ \\
\hline 1990 to 2000 Relative & -0.0007 & -0.002 & 0.002 \\
\hline $\begin{array}{l}\text { Growth Rate in County Pop. } \\
\text { Age 5-17 }\end{array}$ & $(0.0015)$ & $(0.003)$ & $(0.001)$ \\
\hline $\begin{array}{l}\text { State has School } \\
\text { Accountability Rules }\end{array}$ & $\begin{array}{c}0.334 \\
(0.099)\end{array}$ & $\begin{array}{c}0.097 \\
(0.208)\end{array}$ & $\begin{array}{c}0.381 \\
(0.138)\end{array}$ \\
\hline Northeast & $\begin{array}{c}0.006 \\
(0.077)\end{array}$ & $\begin{array}{l}-0.402 \\
(0.126)\end{array}$ & $\begin{array}{l}-0.460 \\
(0.120)\end{array}$ \\
\hline Midwest & $\begin{array}{l}-0.125 \\
(0.084)\end{array}$ & $\begin{array}{l}-0.037 \\
(0.147)\end{array}$ & $\begin{array}{c}0.063 \\
(0.160)\end{array}$ \\
\hline South & $\begin{array}{l}-0.066 \\
(0.053)\end{array}$ & $\begin{array}{c}0.127 \\
(0.072)\end{array}$ & $\begin{array}{c}0.159 \\
(0.074)\end{array}$ \\
\hline African American & $\begin{array}{l}-0.077 \\
(0.051)\end{array}$ & $\begin{array}{c}0.132 \\
(0.084)\end{array}$ & $\begin{array}{c}0.015 \\
(0.049)\end{array}$ \\
\hline Hispanic & $\begin{array}{l}-0.045 \\
(0.059)\end{array}$ & $\begin{array}{l}-0.011 \\
(0.070)\end{array}$ & $\begin{array}{l}-0.153 \\
(0.049)\end{array}$ \\
\hline Smoked since last interview & $\begin{array}{l}-0.0001 \\
(0.0153)\end{array}$ & $\begin{array}{c}0.010 \\
(0.017)\end{array}$ & $\begin{array}{c}0.017 \\
(0.021)\end{array}$ \\
\hline Female & $\begin{array}{c}0.032 \\
(0.016)\end{array}$ & $\begin{array}{c}0.031 \\
(0.026)\end{array}$ & $\begin{array}{c}0.022 \\
(0.023)\end{array}$ \\
\hline Age & $\begin{array}{l}-0.001 \\
(0.008)\end{array}$ & $\begin{array}{l}-0.007 \\
(0.012)\end{array}$ & $\begin{array}{c}0.014 \\
(0.011)\end{array}$ \\
\hline $\begin{array}{l}\text { Family Income } \\
\text { (in } 100 \mathrm{Ks} \text { ) }\end{array}$ & $\begin{array}{c}0.017 \\
(0.024)\end{array}$ & $\begin{array}{c}0.021 \\
(0.028)\end{array}$ & $\begin{array}{l}-0.051 \\
(0.031)\end{array}$ \\
\hline Mother's Education & $\begin{array}{l}-0.003 \\
(0.004)\end{array}$ & $\begin{array}{l}-0.007 \\
(0.007)\end{array}$ & $\begin{array}{l}-0.007 \\
(0.004)\end{array}$ \\
\hline Father's Education & $\begin{array}{l}-0.002 \\
(0.003)\end{array}$ & $\begin{array}{l}-0.007 \\
(0.006)\end{array}$ & $\begin{array}{l}-0.002 \\
(0.005)\end{array}$ \\
\hline Ln(Parent's BMI) & $\begin{array}{c}0.001 \\
(0.034) \\
\end{array}$ & $\begin{array}{l}-0.001 \\
(0.060)\end{array}$ & $\begin{array}{c}0.023 \\
(0.047)\end{array}$ \\
\hline $\begin{array}{l}\text { No. of Observations } \\
\text { R-squared }\end{array}$ & $\begin{array}{c}1007 \\
0.2921\end{array}$ & $\begin{array}{c}1007 \\
0.3029\end{array}$ & $\begin{array}{c}1007 \\
0.4013\end{array}$ \\
\hline $\begin{array}{l}\text { F-statistic for excluded } \\
\text { instruments }\end{array}$ & 10.87 & 1.74 & 6.14 \\
\hline $\begin{array}{l}\text { p-value for excluded } \\
\text { instruments }\end{array}$ & 0.0000 & 0.1709 & 0.0012 \\
\hline
\end{tabular}


Appendix Table 2: Estimated Effect of Food Policy on Ln(BMI)

OLS, IV and Two-Sample Estimation with the "Matched" Sample

\begin{tabular}{|c|c|c|c|c|}
\hline $\begin{array}{l}\text { Policy Variable } \\
\text { \& Est. Method }\end{array}$ & $\begin{array}{l}\text { Coefficient } \\
\text { (Std Err) }\end{array}$ & R-Square & $\begin{array}{l}\text { Mean (SD) of } \\
\text { Policy Var. }\end{array}$ & $\begin{array}{l}\text { Mean (SD) of } \\
\text { Predicted Var. }\end{array}$ \\
\hline \multicolumn{5}{|l|}{ Junk Food } \\
\hline OLS & $\begin{array}{c}0.034 \\
(0.028)\end{array}$ & 0.16 & $\begin{array}{c}0.816 \\
(0.277)\end{array}$ & \\
\hline IV & $\begin{array}{c}0.140 \\
(0.084)\end{array}$ & 0.14 & & \\
\hline Two-Sample & $\begin{array}{c}0.160 \\
(0.117)\end{array}$ & 0.16 & & $\begin{array}{c}0.758 \\
(0.128)\end{array}$ \\
\hline \multicolumn{5}{|l|}{ Pouring Rights } \\
\hline OLS & $\begin{array}{c}0.019 \\
(0.017)\end{array}$ & 0.16 & $\begin{array}{c}0.649 \\
(0.385)\end{array}$ & \\
\hline IV & $\begin{array}{c}0.084 \\
(0.092)\end{array}$ & 0.15 & & \\
\hline Two-Sample & $\begin{array}{c}0.125 \\
(0.103)\end{array}$ & 0.16 & & $\begin{array}{c}0.650 \\
(0.124)\end{array}$ \\
\hline \multicolumn{5}{|l|}{ Snack Food Ads } \\
\hline OLS & $\begin{array}{c}0.034 \\
(0.026)\end{array}$ & 0.16 & $\begin{array}{c}0.427 \\
(0.376)\end{array}$ & \\
\hline IV & $\begin{array}{c}0.146 \\
(0.070)\end{array}$ & 0.13 & & \\
\hline Two-Sample & $\begin{array}{c}0.139 \\
(0.135) \\
\end{array}$ & 0.16 & & $\begin{array}{c}0.410 \\
(0.146)\end{array}$ \\
\hline \multicolumn{5}{|c|}{$\begin{array}{l}\text { Notes: Models also include age, family income, } \ln \text { (parent's BMI), dummies for race, sex, region } \\
\text { (Northeast, Midwest, and South), whether the individual reports smoking since the last interview, } \\
\text { years of education for the biological mother and father, and dummy variables indicating if this } \\
\text { information is missing, and a constant. Standard errors (in parentheses) are adjusted for arbitrary } \\
\text { correlation within county. For the two-sample models, they are also adjusted for the fact that the } \\
\text { policy variable is estimated based on the model shown in appendix table } 1 \text {. All models have } \\
1007 \text { observations and a dependent mean (SD) of } 3.126(0.190) \text {. }\end{array}$} \\
\hline
\end{tabular}




\section{DATA APPENDIX}

Because no one data set contains all of the variables necessary for our analysis, we must build our data from several different sources. These include the School Health Policies and Programs Study (SHPPS), the Common Core of Data for school districts from the National Center for Education Statistics (NCES), county population data from the 1990 and 2000 Census, and individual-level data on public school students from the National Longitudinal Survey of Youth 1997 (NLSY97). We describe our use of each of these in turn.

The SHPPS is a national study conducted in 1994 and 2000 for the Center for Disease Controls (CDC) ${ }^{25}$ While the study covers a broad range of school health policies and procedures at the state, district, school and classroom level, we focus on the 2000 school environment survey. This questionnaire asks about the school's policies regarding such things as the availability of snack foods through vending machines, school stores and snack bars; the details of an exclusive contract with a soft drink manufacturer (if any); and the types of advertising for sodas and snack foods allowed. Unfortunately, the majority of these questions were not asked in 1994. While unlike the 1994 study, the 2000 study also includes elementary schools, we do not include them in our main analysis, since we will be focusing on youths age 14 and older who are enrolled in public schools.

We choose three food policies from the SHPPS for the bulk of our analysis. First is an indicator of student access to junk foods, defined as the availability through vending machines or school stores of chocolate candy; other candy; cookies, crackers, cakes, pastries or other baked goods that are not low in fat; or salty snacks that are not low in fat. Second is an indicator for having an exclusive "pouring rights" contract with a soft drink manufacturer. Third is an

\footnotetext{
${ }^{25}$ For more information on SHPPS, see http://www.cdc.gov/nccdphp/dash/shpps/.
} 
indicator that advertisements promoting student consumption of candy, meals from fast food restaurants or soft drinks are permitted in any number of ways, such as in the school building, on textbook covers or food service menus, on buses, or at athletic fields.

Since we are focusing on public school financing issues, we limit ourselves to the public schools in the SHPPS. We use data on the 451 public middle and high schools for which all the variables we need have non-missing information. For these schools we can identify their school district and merge on district-level information about school finances from the NCES Common Core of Data. ${ }^{26}$ The SHPPS data give the QED (Quality Education Data) district codes. We purchased the cross-walk between the QED and NCES district codes from QED. We use the NCES district codes to merge data on district finance information from the NCES. While detailed financial data is available, we want a simple summary measure of local fiscal capacity. Thus, we choose to use the fraction of total district revenues that come from the state, since even state funding formulas that are not explicitly equalization schemes, such as the most common foundation grant formula, result in there being a negative correlation between local fiscal capacity and the state share of funding. ${ }^{27}$

The lowest geographic level of detail available in our individual-level data sets is the county. We therefore aggregate the SHPPS and NCES data up to the county level. ${ }^{28}$ Using the school weights in the SHPPS, then, we calculate the probability that a school in the county has each of these policies. There are 180 counties in 41 states covered in our SHPPS sample. The NCES fiscal data is averaged across all districts in the county using district enrollment levels as

\footnotetext{
${ }^{26}$ More information about the NCES Common Core of Data can be found at http://nces.ed.gov/ccd/. The latest fiscal data available at the time the project began was for the 1998-1999 school year. Thus, the fiscal data lags the policy data by one year.

${ }^{27}$ See, for example, the summary discussion of Public School Finance Programs in the United States and Canada by Sielke and Holmes at http://www.ed.sc.edu/aefa/reports/ch1.pdf.

${ }^{28}$ The NCES identifies the county in which the district headquarters is located.
} 
weights. Finally, we merge on two state-level indicators and the county-level relative growth in the school-age population. The first indicator is for whether the state has tax and expenditure limitations in place. ${ }^{29}$ These types of local limits were commonly passed beginning in the late 1970s and into the 1980s, with some states tightening their laws in the early 1990s. The second indicator is for whether a state has passed a school accountability measure. These types of laws are mainly of a much more recent vintage, with many not implemented until the mid-1990s. Data appendix table 1 provides a complete list of states with each of these types of laws and the dates they were implemented. Finally, we compute the relative growth rate for the school-age population based on county-level population figures for those age 5-17 and the total population from the 1990 and 2000 Census. The growth rate is then calculated as:

Ln(age 5-17 population in 2000)-Ln(age 5-17 population in 1990) divided by $\operatorname{Ln}($ total population in 2000)- $\operatorname{Ln}($ total population in 2000).

Table 2 includes the sample means of each of these predictor variables.

The second major component of the project uses individual level data on adolescents that includes height and weight, along with individual and family background demographics. The National Longitudinal Survey of Youth, 1997 panel (NLSY97) is a survey of 8984 youths who were age 12-16 as of December 31, 1996. The first round of the survey took place between February of 1997 and May of 1998. Additional waves have been carried out annually during the school year. We use data from wave 3, which was collected in the 1999-2000 school year, to be in accord with the SHPPS data.

Wave 3 of the data contains information on 7958 individuals. We limit that to those who are enrolled in public school, which reduces the sample to 4653 individuals. By the time we eliminate those with missing information for variables used in our analysis, we are left with a

\footnotetext{
${ }^{29}$ These laws are from Downes and Figlio (1999), updated to reflect the 2000 status. 
working sample of 3482 individuals. In order to use our two step estimation, we append the data on state tax limitations and state accountability laws to the NLSY97 data using state identifiers provided in the confidential geocode data. Similarly, we append county level data on the share of total school revenue from state sources, and the 1990 to 2000 relative growth rate in the county population aged 5-17 using the county identifiers in the geocode data. The individuals in our NLSY97 sample live in 426 counties.

We measure the adolescents' weight status using the log of their body mass index (BMI). BMI is defined as weight in kilograms divided by height in meters squared $\left(\mathrm{kg} / \mathrm{m}^{2}\right)$ and is a commonly used measure to define obesity and overweight in adults. For example, according to guidelines in National Institutes of Health (1998), adults are considered underweight if their BMI is less than 18.5 , overweight if their BMI is 25 or more, and obese if their BMI is 30 or more. Use of the BMI to assess children and adolescents has been slightly more controversial, although its use is fairly widespread. ${ }^{30}$ The Centers for Disease Control (CDC) has recently endorsed the use of BMI to assess overweight status in children and adolescents, and has produced sexspecific BMI distributions for children aged 2 to 20 for just this purpose. While results are similar using probability of overweight, we choose to use the continuous BMI measure.

Before calculating BMI, however, we make a few corrections for obvious typographical problems with the recorded height and weight data. As a first step in cleaning the weight data, we replace any weight value in a given year with the average from the years surrounding it if the

\footnotetext{
${ }^{30}$ Ideally, one would prefer to measure overweight using a measure that reflects adiposity. Since it is impractical to do so in large scale surveys, researchers have employed the BMI, which only requires the measurement of height and weight. It is somewhat controversial when used to assess overweight among children because children experience growth spurts at individual-dependent ages and this can weaken the relationship between height and weight-based measures to adiposity. See Freeman, et al. (1995) and Whitaker, et al. (1997) for a discussion of the use of BMI in children. Recently, Dietz and Bellizzi (1999) reporting on a conference convened by the International Obesity Task Force, noted that the BMI "offered a reasonable measure with which to assess fatness in children and adolescents." Additionally, they conclude that a BMI above the $85^{\text {th }}$ percentile for a child's age and sex group is likely to accord with the adult definition of overweight, and above the $95^{\text {th }}$ percentile with the adult definition of
} 
given value is less than half or more than double the average of those surrounding it. So for example, for a wave 3 weight observation, we replace it with the average of the wave 2 and wave 4 weight values if it is less than half or more than double the average of the wave 2 and 4 values.

Because several individuals are missing weight data for one or more years, this presents a problem in comparing a given weight value to the values surrounding it. So, we employ an additional screening method. We flag weight values less than 60 or greater than 300 and then examine them by hand to distinguish between those individuals who have consistently high or consistently low weights and those individuals who have a single weight value which is very different from all other available weight data for that individual. For those individuals who have an outlier weight value, we replace it with the average of the weight values from the closest waves.

After creating the BMI values, we then flag any value which is less than 10 or greater than 40 . We chose 10 and 40 as our cutoff values because the 3 rd percentile for a 12 year-old is around 15 and the 97 th percentile for a 20 year-old is 35 . For those individuals with a flagged BMI, we then examine the height values by hand in order to identify those height values which clearly stand out from the rest. In all cases, only the feet value of height is altered since it is virtually impossible to determine if the inches values are inaccurate. The outlier height values are replaced with the nearest height value that makes sense. For example an individual who has the height values 5'10", 8'11', 5'11', 5'11', 6’0” will have the 8' replaced with 5'. An individual who has the height values 4'11', 7'2”, 5'2”, 5'3”, 5'3" will have the 7' replaced with 5'. Finally, the BMI values are recomputed using the altered weights and altered heights.

obese. 
Ultimately, only 5 sample BMI values are different from those computed from the recorded values.

We also use parental BMI in the analysis. This information was collected in the initial wave from the responding parent $(88 \%$ are biological mothers, $10 \%$ are biological fathers, $3 \%$ are related female guardians, and $2 \%$ are stepmothers). There are outliers in these data as well, but with only 1 year of information, we cannot follow the procedure described above for identifying incorrect information. Bad data leading to the misidentification of students as having "obese" parents may explain why our results for that subgroup are relatively imprecise. Without other information, our options for dealing with misreported data are limited. We re-estimated the results in table 3 dropping those with parents with BMIs above 40, above 50, and above 60 . These three sets of results are very similar to those in table 3 .

One other key explanatory variable needs some re-coding. We want to control for an individual's socioeconomic background, so we construct a variable that will capture each individual's permanent household income. Because the youth in our sample are all enrolled in public schools, in most cases this variable is the average of the gross household income values of a youth's parents over the period 1996-2000 (collected in 1997-2001). For 1996, we use a gross household income variable which was constructed using information collected during the initial parent interview. ${ }^{31}$ For 1997 through 2000, we use gross household income variables constructed using information from household income update questionnaires. The household income update questionnaires were administered each survey year to the parents of individuals who still lived at home. They collected the following information:

- whether or not the parent had an income

\footnotetext{
${ }^{31}$ In a few cases ( $2 \%$ of the full sample), youth who were considered independent answered these income questions instead of the parent.
} 
- the amount of the parent's income if it existed

- whether or not the parent's spouse/partner had an income

- whether or not the parent and spouse/partner had any other forms of income

- the amount of the other income if it existed

The gross household income variables we use for 1997 through 2000 are created so that income from a particular source is zero if the parent responding reports that they did not have that type of income, is the amount of that type of income if the amount is available and the parent reports that they do have that type of income, and is missing otherwise. The income amounts from each of the three distinct sources are then summed to get a gross household income variable for 19972000. For these years, if the gross household income value is still missing after using the household income update information, we replace it with a household income value which was collected from each youth age 14 and older in the 1998-2001 surveys. ${ }^{32}$ We then convert each of these final gross household income variables to 2000 dollars. Finally, in order to get a variable representative of "permanent" household income, we average gross household income across all years, 1997-2001. We replace this permanent household income value with a missing value if we do not have at least two years of valid household income data to calculate the average.

\footnotetext{
32 The survey requested income information for parents if the youth was considered dependent. However, if the youth was considered independent, the survey requested income information for all individuals age 14 and older in the household.
} 
Data Appendix Table 1: Summary Statistics

\begin{tabular}{|c|c|c|}
\hline & Full Sample & Matched Sample \\
\hline \multirow[t]{2}{*}{ White } & 0.686 & 0.587 \\
\hline & $(0.464)$ & $(0.493)$ \\
\hline \multirow[t]{2}{*}{ Black } & 0.151 & 0.162 \\
\hline & $(0.358)$ & $(0.369)$ \\
\hline \multirow[t]{2}{*}{ Hispanic } & 0.117 & 0.204 \\
\hline & $(0.322)$ & $(0.403)$ \\
\hline \multirow[t]{2}{*}{ Smoked since last interview } & 0.348 & 0.302 \\
\hline & $(0.476)$ & $(0.460)$ \\
\hline \multirow{2}{*}{ Female } & 0.471 & 0.458 \\
\hline & $(0.499)$ & $(0.499)$ \\
\hline \multirow[t]{2}{*}{ Age } & 16.2 & 16.26 \\
\hline & $(1.10)$ & $(1.08)$ \\
\hline Family Income & 0.556 & 0.605 \\
\hline (in $\$ 100 \mathrm{Ks}$ ) & $(0.429)$ & $(0.482)$ \\
\hline \multirow[t]{2}{*}{ Biological Mother's Education } & 12.3 & 12.1 \\
\hline & $(3.84)$ & $(4.16)$ \\
\hline \multirow[t]{2}{*}{ Biological Father's Education } & 11.2 & 10.8 \\
\hline & $(5.25)$ & $(5.70)$ \\
\hline \multirow{2}{*}{ Bio. Mom's Education Missing } & 0.051 & 0.064 \\
\hline & $(0.220)$ & $(0.245)$ \\
\hline \multirow[t]{2}{*}{ Bio. Dad's Education Missing } & 0.137 & 0.172 \\
\hline & $(0.344)$ & $(0.378)$ \\
\hline \multirow[t]{2}{*}{ Northeast } & 0.163 & 0.162 \\
\hline & $(0.370)$ & $(0.369)$ \\
\hline \multirow[t]{2}{*}{ Midwest } & 0.278 & 0.224 \\
\hline & $(0.448)$ & $(0.417)$ \\
\hline \multirow[t]{2}{*}{ South } & 0.331 & 0.253 \\
\hline & $(0.471)$ & $(0.435)$ \\
\hline \multirow[t]{2}{*}{ West } & 0.228 & 0.361 \\
\hline & $(0.419)$ & $(0.481)$ \\
\hline \multirow[t]{2}{*}{ BMI } & 22.99 & 23.23 \\
\hline & $(4.63)$ & $(4.95)$ \\
\hline \multirow[t]{2}{*}{$\operatorname{Ln}(\mathrm{BMI})$} & 3.12 & 3.13 \\
\hline & $(0.018)$ & $(0.190)$ \\
\hline \multirow[t]{2}{*}{ Obese } & 0.109 & 0.116 \\
\hline & $(0.312)$ & $(0.321)$ \\
\hline \multirow[t]{2}{*}{ Overweight } & 0.242 & 0.247 \\
\hline & $(0.428)$ & $(0.432)$ \\
\hline \multirow[t]{2}{*}{ Parent's BMI } & 26.53 & 26.38 \\
\hline & $(5.87)$ & $(5.50)$ \\
\hline \multirow[t]{2}{*}{ Ln(Parent's BMI) } & 3.26 & 3.25 \\
\hline & $(0.204)$ & $(0.198)$ \\
\hline \multirow[t]{2}{*}{ Parents Obese } & 0.228 & 0.230 \\
\hline & $(0.419)$ & $(0.421)$ \\
\hline \multirow[t]{2}{*}{ Parents Overweight } & 0.518 & 0.533 \\
\hline & $(0.500)$ & $(0.499)$ \\
\hline Sample Size & 3482 & 1007 \\
\hline
\end{tabular}

Notes: Mean and (standard deviation) shown. The data are from the 1999 panel of the NLSY97. The "full" sample is for all individuals who attend public school and for whom we have information for the full set of variables listed here. The "matched" sample is for only those individuals who live in counties that overlap with those sampled in the School Health Policies and Programs survey. See text for additional information about the samples. 
Data Appendix Table 2: Tax and Expenditure Limits and School Accountability By State

\begin{tabular}{|c|c|c|c|c|}
\hline State & $\begin{array}{c}\text { Tax and Expenditure } \\
\text { Limits }\end{array}$ & $\begin{array}{c}\text { Year of Enactment, } \\
\text { Tightening }\end{array}$ & $\begin{array}{c}\text { School } \\
\text { Accountability }\end{array}$ & $\begin{array}{l}\text { Year System } \\
\text { Implemented }\end{array}$ \\
\hline Alabama & No & & Yes & 1997 \\
\hline Alaska & No & & No & \\
\hline Arizona & Yes & 1975,1990 & Yes & 2000 \\
\hline Arkansas & Yes & 1982 & Yes & 1999 \\
\hline California & Yes & 1978 & Yes & 1999 \\
\hline Colorado & Yes & 1974,1990 & Yes & 1999 \\
\hline Connecticut & No & & Yes & 1984 \\
\hline Delaware & No & & Yes & 1998 \\
\hline District of Columbia & No & & Yes & 1997 \\
\hline Florida & No & & Yes & 1999 \\
\hline Georgia & No & & Yes & 2000 \\
\hline Hawaii & No & & No & \\
\hline Idaho & No & & No & \\
\hline Illinois & No & & No & \\
\hline Indiana & Yes & 1974 & Yes & 1995 \\
\hline Iowa & Yes & 1972, 1992 & No & \\
\hline Kansas & Yes & 1974 & Yes & 1995 \\
\hline Kentucky & Yes & 1980 & Yes & 1995 \\
\hline Louisiana & Yes & 1979 & Yes & 1999 \\
\hline Maine & No & & Yes & 1999 \\
\hline Maryland & No & & Yes & 1999 \\
\hline Massachusetts & Yes & 1981 & Yes & 1998 \\
\hline Michigan & Yes & 1979 & Yes & 1998 \\
\hline Minnesota & Yes & 1972 & Yes & 1996 \\
\hline Mississippi & Yes & 1984 & Yes & 1994 \\
\hline Missouri & Yes & 1981 & Yes & 1997 \\
\hline Montana & Yes & & Yes & 1998 \\
\hline Nebraska & No & & No & \\
\hline Nevada & No & & Yes & 1996 \\
\hline New Hampshire & No & & Yes & 1993 \\
\hline New Jersey & Yes & 1977 & Yes & 1995 \\
\hline New Mexico & Yes & 1980 & No & \\
\hline New York & No & & Yes & 1998 \\
\hline North Carolina & No & & Yes & 1993 \\
\hline North Dakota & No & & No & \\
\hline Ohio & Yes & 1977 & Yes & 1998 \\
\hline Oklahoma & No & & Yes & 1996 \\
\hline Oregon & Yes & 1991 & Yes & 2000 \\
\hline Pennsylvania & No & & Yes & 1997 \\
\hline Rhode Island & No & & Yes & 1997 \\
\hline South Carolina & Yes & 1981 & Yes & 1999 \\
\hline South Dakota & No & & No & \\
\hline Tennessee & No & & Yes & 1996 \\
\hline Texas & Yes & 1983 & Yes & 1994 \\
\hline Utah & No & & No & \\
\hline Vermont & No & & Yes & 1999 \\
\hline Virginia & No & & Yes & 1998 \\
\hline Washington & Yes & 1980 & Yes & 1998 \\
\hline West Virginia & No & & Yes & 1997 \\
\hline Wisconsin & No & & Yes & 1993 \\
\hline Wyoming & No & & Yes & 1999 \\
\hline
\end{tabular}

Source: Tax and Expenditure Limit information is from David Figlio for 2000, from data used in "Do tax and expenditure limits provide a free lunch? Evidence on the links between limits and public sector service quality" (Downes and Figlio, 1999). School Accountability Information is from Mackie Raymond for 2000, from data used in "Improving Educational Quality: How Best to Evaluate Our Schools" (Hanushek and Raymond, 2002). 